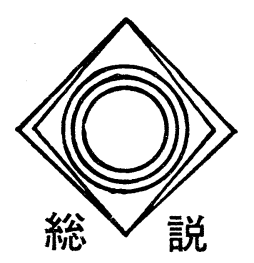

石炭液化反応における

\section{鉄系触媒の効果}

東京大学 神谷佳 男

\section{1. はしがき}

石炭の液化反応 ${ }^{122}$ は, 固体高分子である石炭が熱 分解して溶媒中に溶解, 分散し, プレアスファルテン およびアスファルテンを生成する第一段階と, これら がさらに水素化分解してオイルを生成する第二段階に 分けることができる。

水素化活性を有する触媒 3 (3) が石炭液化飞作用する 機構は複雑である。第一段階においては, 芳香族溶媒 を水素化してその水素供与性5)6)を向上させ, 液化を 円滑に進行させる効果があり, また溶解分散したフラ グメントを水素化により安定化し, 再結合によるチャ 一の生成を抑制する作用がある。さらに，アスファル テンを水素化分解して軽質分を生成する効果があり, これがもっとも重要な触媒効果であらう。いずれも, 石炭の反応率, プレアスファルテン, アスファルテン およびオイルの収率により, その効果を識別すること ができる。

石炭の熱分解, 溶解反応飞打いて, 溶媒の水素供与 性が重要な役割を果たすことは,すでに著名の事実で ある。効果の大きなものは, 水素化芳香族7であり, テトラリンが著名であるが, ジヒドロフェナントレン やジヒドロアントラセンの方が有効であることが明ら かにされており, さらにジヒドロピレンが優れた効果 を有することが知られている。多環芳香族が優秀な効 果を示す理由としては，(1)芳香族環が容易に水素化さ れてヒドロ芳香族となる，(2)七ドロ芳香族は $\mathrm{C}-\mathrm{H}$ 結 合解離エネルギーの小さいベンジル水素をもつ, (3)水 素化と脱水素をくり返すことにより効果的に作用す る，(4)石炭の分解生成物をよく溶解する,などがあげ られる。

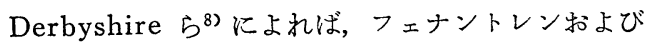
ピレンの水素化反応はかなり速く，とくにピレンは硫 化鉄触媒によっても，かなりの速度で水素化されるこ とが確かめられている。加圧水素存在下で, 少量のピ 工学部反応化学科 東京都文京区本郷 7 丁目
レンを溶媒に添加すると，石炭の液化反応が著しく促 進されるのは，上記の理由によると考兄られている。 石炭が含有する鉱物質（いわゆる灰分）はかなりの硫 化鉄を含有するため, 水素存在下の石炭液化反応の速 度は，灰分含有量に比例するとの報告6) あある。

石炭からガソリン，燈軽油など留出油を高収率で生 成するためには, 触媒を用いる高度の水素化分解反 沁 ${ }^{9}$ が不可欠である。石炭は縮合芳香族環を主体と し, 相当量の $\mathrm{O}, \mathrm{N}, \mathrm{S}$ な゙゙へテロアトムを含む化学 構造から成り立っているため, 同時に芳香族環の水素 化分解, 脱酸素, 脱硫, 脱咀素など多種類の水素化と 分解をともなう複雑な反応を進行させる必要がある。

触媒としては，(1)硫化鉄を主体とする鉄系化合物， (2)塩化亜鉛拉よび塩化錫など金属八ロゲン化物，(3)モ リブデンまたはタングステンを主成分とする石油留分 の水素化精製用触媒, などが検討されている。

(1)は活性があまり高くないが，安価でしか子廃棄可 能であるため, 第 2 次大戦中のドイッではこの系列の 触媒がもっぱら使用された。(3)は高活性であり重油脱 硫関連して高性能の触媒が開発されているが, 石炭 液化反応に打いては，比較的速やかに活性が低下する といら欠点がある。

本総説では, 作用機構に不明の点が多く, 活性の高 い触媒の開発が要望されている鉄系触媒について, 最 近の研究成果を概説することにする。1978年以前の報 文については前総説4を参照され度い。

\section{2. 各種鉄系化合物の添加効果}

米国の歷青炭 (Elkhorn No. 3, C 81.3\% daf) を $426^{\circ} \mathrm{C}$ 拈よび $454^{\circ} \mathrm{C}, 140 \mathrm{~kg} / \mathrm{cm}^{2}$ で液化した場合におけ る Pyrite $\left(\mathrm{FeS}_{2}\right)$ の添加効果 ${ }^{10)}$ を表 1 亿示す。

添加の結果, 石炭反応率拈よび水素消費量は増加し, 低分子成分であるベンゼン可溶分が大きく増加してい るので, 石炭の溶解反応, 水素化反応, 水素化分解反 応が著しく促進されていることが明らかである。

豪州褐炭 (Yallourn C $66 \%$ daf) の液化反応 ${ }^{11}$ に 
表 1 石炭液化における Pyrite 添加効果 $^{10)}\left(\right.$ Elkhorn 炭, $\left.140 \mathrm{~kg} / \mathrm{cm}^{2}\right)$

\begin{tabular}{|c|c|c|c|c|}
\hline $\mathrm{Wt} \% \mathrm{MAF}$ Coal & $\begin{array}{l}70 \% \text { Solvent } \\
30 \% \text { Coal } \\
454^{\circ} \mathrm{C}\end{array}$ & $\begin{array}{c}60 \% \text { Solvent } \\
30 \% \text { Coal } \\
10 \% \text { Pyrite } \\
454^{\circ} \mathrm{C}\end{array}$ & $\begin{array}{c}70 \% \text { Solvent } \\
30 \% \text { Coal } \\
426{ }^{\circ} \mathrm{C}\end{array}$ & $\begin{array}{c}60 \% \text { Solvent } \\
30 \% \text { Coal } \\
10 \% \text { Pyrite } \\
426{ }^{\circ} \mathrm{C}\end{array}$ \\
\hline HC Gas & 4.2 & 5.3 & 2.4 & 2.0 \\
\hline $\mathrm{CO} / \mathrm{CO}_{2}$ & 1.0 & 1.2 & 0.8 & 0.9 \\
\hline $\mathrm{H}_{2} \mathrm{~S}$ & 1.3 & 2.8 & 0.9 & 0.9 \\
\hline $\mathrm{NH}_{3}$ & 0 & 0.2 & 0 & 0 \\
\hline Benzene Solubles* & 42.1 & 52.3 & 14.4 & 30.5 \\
\hline Preasphaltenes & 30.1 & 24.3 & 58.0 & 49.3 \\
\hline IOM & 18.1 & 10.4 & 20.6 & 13.7 \\
\hline Water & 3.2 & 3.5 & 2.9 & 2.7 \\
\hline Conversion & 81.9 & 89.6 & 79.4 & 86.3 \\
\hline H Consumption Total & 1.4 & 2.53 & 0.51 & 1.65 \\
\hline Gas & 0.82 & 2.49 & 0.61 & 1.82 \\
\hline Solvent & 0.58 & 0.04 & 0.1 & 0.17 \\
\hline Pyrite & - & 0.50 & - & 0.5 \\
\hline $\mathrm{SRC} \% \mathrm{~S}$ & 0.61 & 0.68 & 0.79 & 0.71 \\
\hline $\begin{array}{l}\mathrm{H} \text { Content of } \mathrm{Oil} \\
\quad \text { (original } 7.72 \%)\end{array}$ & 7.49 & 7.70 & 7.76 & 7.80 \\
\hline
\end{tabular}

*Oil+Asphaltene

表 2 ヤルーン褐炭の液化における鉄系触媒の効果

\begin{tabular}{|c|c|c|c|c|c|c|}
\hline $\begin{array}{l}\text { Additive } \\
(\mathrm{g})\end{array}$ & None & $\begin{array}{l}\mathrm{Fe}_{2} \mathrm{O}_{3} \\
(2.0)\end{array}$ & $\begin{array}{l}\mathrm{Fe}_{2} \mathrm{O}_{3}(2.0) \\
\mathrm{S}(0.8)\end{array}$ & $\begin{array}{l}\text { Ferrocene } \\
(2.0)\end{array}$ & $\begin{array}{l}\text { Ferrocene }(2.0), \\
\mathrm{S}(0.8)\end{array}$ & $\begin{array}{c}\mathrm{Fe}_{2} \mathrm{SO}_{4} 7 \mathrm{H}_{2} \mathrm{O} \\
(2.0)\end{array}$ \\
\hline $\begin{array}{l}\text { Coal Conversion } \\
(\mathrm{wt} \%)\end{array}$ & 67 & 71 & 87 & 79 & 87 & 74 \\
\hline $\begin{array}{l}\mathrm{SRC} \\
\quad \text { fraction }(w t \%)\end{array}$ & 35 & 38 & 51 & 44 & 53 & 39 \\
\hline $\begin{array}{l}\text { Hydrogen } \\
\text { consumption } \\
(\text { wt } \% \text { of daf coal) }\end{array}$ & 0 & 0.56 & 2.6 & 1.4 & 2.4 & 4.6 \\
\hline \multicolumn{7}{|c|}{ TLC-FID Analyses of THF-soluble fraction } \\
\hline A\&B Fractions $(w t \%)$ & 42 & 44 & 46 & 42 & 42 & 31 \\
\hline C Fraction $(w t \%)$ & 58 & 56 & 54 & 58 & 58 & 69 \\
\hline
\end{tabular}

反応条件: $400^{\circ} \mathrm{C}, 30$ 分, 石炭 $20 \mathrm{~g}$, 水素初圧 $50 \mathrm{~kg} / \mathrm{cm}^{2}$, テトラリン $15 \mathrm{~m} \ell, 1$ メチルナフタレン $45 \mathrm{~m} \ell$

打いて，酸化鉄，フェロセン，硫酸鉄は石炭の反応率 の増加に対して，かなり有効であるが，さらにイオウ を添加することにより硫化鉄を生成させると，石炭の 反応率はさらに上昇するが，オイル十ガス（石炭の反 応率-SRC) についても増加の傾向が見うけられる (表 2)。

表 3 は SRC の水素化分解に詨する鉄系触媒の効果 を比較したものである。触媒添加により重合反応が抑 制され, 分解反応が促進される傾向が明らかに認めら れる。水素分圧が高い方が好結果を与兄ている。
表2に拈いても認められたよらに，フェロセンが好 結果を与えるのは，油溶性の化合物であるために，一 度溶解分散したのち，高温で熱分解し，微細な純鉄を 析出するためであると推定される。

な打，溶媒として水素供与性の低いメチルナフタレ ンを使用したために，有機不溶分が高い值を示してい る。水素供与性の高いテトラリン中では重合物質の生 成を抑制できるが， 450 ํㅡㄴ 以下て溶媒の効果が大き いために，触媒効果があまり顕著でない。

石炭の種類により触媒効果は変化する。Alexan一 
der ら ${ }^{12}$ によれば，4 種類の石炭について Pyrite の 効果は著しく, 全オイル量は増加し， SRC および有 機不溶分 (IOM) は著しく低下している。もっとも効 果の大きい Belle Ayr 执よび McKinley はいずれ も亜歴青炭であり，初期に和ける熱分解，液化反応が
比較的速やかであることや，含有鉱物質の組成が影響 するところが大きいためと推測される。低石炭化度炭 の液化に和いては，溶媒の水素供与性が重要な因子で ありまたPyrite の含有量が比較的少ないためであ ろら。

表 3 SRC (原料 ヤルーン 褐炭) の水素化分解における鉄系触媒の効果

\begin{tabular}{|c|c|c|c|c|c|}
\hline $\begin{array}{l}\text { Initial } \mathrm{H}_{2} \\
\text { pressure }\left(\mathrm{kg} / \mathrm{cm}^{2}\right)\end{array}$ & 50 & 50 & 50 & 50 & 80 \\
\hline Additive & none & Ferrocene & $\mathrm{Fe}_{2} \mathrm{O}_{3}$ & Ferrocene & Ferrocene \\
\hline$(\mathrm{g})$ & 1.0 & 1.0 & 1.0 & 0.3 & 0.3 \\
\hline Organic Residue(g) & 1.10 & 0.23 & 0.34 & 0.15 & 0.07 \\
\hline (wt $\%)$ & $(36.9)$ & $(7.7)$ & $(11.1)$ & $(5.0)$ & $(2.3)$ \\
\hline Recovered SRC(g) & 1.45 & 2.03 & 2.10 & 1.80 & 1.79 \\
\hline$($ wt $\%)$ & $(48.7)$ & $(67.4)$ & $(69.1)$ & $(60.0)$ & $(59.7)$ \\
\hline \multicolumn{6}{|l|}{ Decomposed SRC } \\
\hline$(w t \%)$ & $(14.4)$ & $(24.9)$ & $(19.8)$ & $(35.0)$ & $(38.0)$ \\
\hline $\begin{array}{l}\text { Hydrogen Consumption } \\
\text { (wt } \% \text { of Initial SRC) }\end{array}$ & 0.6 & 4. 0 & 3.6 & 3.9 & 5.3 \\
\hline
\end{tabular}

反応条件： $\mathrm{SRC} 3.0 \mathrm{~g}, 1$-メチルナフタレン $15 \mathrm{~m} \ell, 450^{\circ} \mathrm{C}, 60$ 分

表 4 各種石炭の液化における Pyrite 添加効果 ${ }^{12)}$

(Pyrite をスラリーに対し $1.86 \mathrm{wt} \%$ 添加前後に拈ける生成物の差)

\begin{tabular}{lccccc}
\hline Coal & Belle Ayr & Kaiparowits & McKinley & Edna & Blacksville \\
\hline Change in MAF Yields & & & & & -0.1 \\
$\quad$ C $_{1}-\mathrm{C}_{4}$ & +1.8 & +0.2 & -0.9 & -2.3 & +2.6 \\
Total Oil & +22.0 & +16.7 & +20.3 & +14.9 & -0.7 \\
SRC & -12.2 & -9.0 & -10.5 & -9.1 & +0.3 \\
IOM & -12.0 & -6.1 & -6.0 & -1.8 & +0.7 \\
Change in MAF & +0.1 & +1.3 & +2.2 & +1.8 & + \\
Hydrogen Consumption & & & & \\
\hline
\end{tabular}

反応条件： $450^{\circ} \mathrm{C}, 160 \mathrm{~kg} / \mathrm{cm}^{2}, 60$ 分，石炭濃度 $30 \mathrm{wt} \%$ /スラリ一, 水素送入量 $4 \mathrm{wt} \%$ /スラリ一

表 5 石炭液化における添加物の効果 ${ }^{13)}$

\begin{tabular}{|c|c|c|c|c|c|c|c|c|}
\hline \multirow{2}{*}{ 湑 加 物 } & \multirow{2}{*}{$\begin{array}{l}\text { 初王: } \\
10^{3} \text { psi }\end{array}$} & \multirow{2}{*}{$\begin{array}{l}\text { 終田 } \\
10^{3} \mathrm{psi}\end{array}$} & \multicolumn{3}{|c|}{ 分圧 psi } & \multirow{2}{*}{$\begin{array}{c}\text { 液状生成物 } \\
\text { ○ S 含䱏 } \\
\text { wt \% }\end{array}$} & \multirow{2}{*}{$\begin{array}{l}\text { 水素压比 } \\
\left(\begin{array}{c}\text { 終圧/ } \\
\text { 初王 }\end{array}\right)\end{array}$} & \multirow{2}{*}{$\begin{array}{l}\text { テトラリン比 } \\
\text { チフタリン }\end{array}$} \\
\hline & & & $\mathrm{H}_{2}$ & $\mathrm{H}_{2} \mathrm{~S}$ & $\mathrm{CH}_{4}$ & & & \\
\hline $\mathrm{Co}-\mathrm{Mo} / \mathrm{Al}_{2} \mathrm{O}_{3}$ & 2.01 & 1.32 & 650 & 110 & 203 & 0.22 & 0.35 & 0.49 \\
\hline $\mathrm{SRC}$ 法残渣 & 2.01 & 1.46 & 805 & 41 & 220 & 0.38 & 0.43 & 0.33 \\
\hline fly ash & 2.01 & 1.39 & 854 & 20 & 179 & 0.37 & 0.45 & 0.29 \\
\hline $\mathrm{Fe}$ & 2.00 & 1. 46 & 1,040 & 0 & 150 & 0.25 & 0.56 & 0.25 \\
\hline $\mathrm{CuO}$ & 2.00 & - & - & -- & -- & 0.26 & 0.63 & - \\
\hline $\mathrm{CaO}$ & 2.00 & - & - & - & - & 0.34 & 0.83 & - \\
\hline なし & 2.07 & 1. 64 & 1,190 & 39 & 150 & 0.39 & 0.64 & 0.16 \\
\hline
\end{tabular}

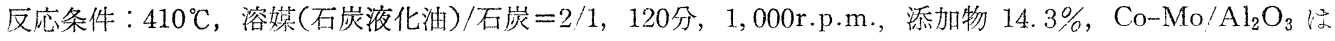
前硫化処理 
表 6 石炭液化になける $\mathrm{Fe}$ 添加量の効果 ${ }^{13)}$

\begin{tabular}{|c|c|c|c|c|c|c|c|}
\hline \multirow{2}{*}{$\mathrm{Fe}, \mathrm{wt} \%$} & \multirow{2}{*}{$\begin{array}{c}\text { 初圧 } \\
10^{3} \mathrm{psi}\end{array}$} & \multirow{2}{*}{$\begin{array}{c}\text { 終圧 } \\
10^{3} \mathrm{psi}\end{array}$} & \multicolumn{3}{|c|}{ 分圧, psi } & \multirow{2}{*}{$\begin{array}{c}\text { 液状生成物 } \\
\text { 量 } \\
\text { wt } \%\end{array}$} & \multirow{2}{*}{$\begin{array}{l}\text { 水 素 圧 比 } \\
\text { (終圧/初圧) }\end{array}$} \\
\hline & & & $\mathrm{H}_{2}$ & $\mathrm{H}_{2} \mathrm{~S}$ & $\mathrm{CH}_{4}$ & & \\
\hline 0 & 2.07 & 1.44 & 1,200 & 39 & 150 & 0.39 & 0.52 \\
\hline 1.0 & 2.21 & 1.70 & 1,190 & .5 .9 & 114 & 0.37 & 0.57 \\
\hline 2.0 & 1.59 & 1.29 & 812 & 0 & 180 & 0.35 & 0.56 \\
\hline 4.0 & 1.73 & 1.32 & 893 & 0 & 155 & 0.35 & 0.57 \\
\hline 7.7 & 2.07 & 1.59 & 1,130 & 0 & 162 & 0.28 & 0.59 \\
\hline 13.3 & 2.00 & 1.46 & 1,040 & 0 & 150 & 0.25 & 0.56 \\
\hline
\end{tabular}

（反応条件：表 5 に同じ）

石炭液化に扣ける各種添加物の効果を, 脱硫拈よび 水素化の観点から比較した Guin ら ${ }^{13)}$ の結果を表 5 に 示す。

もっとも脱硫活性の高い添加物は $\mathrm{Co}-\mathrm{Mo} / \mathrm{Al}_{2} \mathrm{O}_{3}$, ついで $\mathrm{Fe}$ である。この時 $\mathrm{Fe}$ は $\mathrm{FeS}$ に変化してい ると考克られ，気相中の $\mathrm{H}_{2} \mathrm{~S}$ 分圧は 0 になっている。 したがって，Fe 水水素化分解を行っているといらよ りむしろ，単にイオウの捕捉剤として機能しているの であらう。

水素の消費量から見てもっとも高活性の添加物は， Co-Mo であり, ついで SRC 法残渣, fly ash, Fe の 順である。

表 6 は同じくGuin ら ${ }^{13)}$ とよる Fe の添加量の効果 を示したもので岗る。Fe の添加量に比例して生成油 中のイオウ含有量が低下し，脱硫効果が增加する事実 が認められるが，水素消費量は $\mathrm{Fe}$ が $2 \%$ から $13 \%$ K 增加してもほとんど変化しない。Fe の添加量を $2 \%$ 以上にすると， $\mathrm{H}_{2} \mathrm{~S}$ の分圧が 0 となるので，添加量の 増加により脱硫反応はより高度に進行するが，水素化 分解の方は活性の高い硫化鉄触媒があまり生成しない ために大きな変化は認められないのであるう。

次のような水素化，脱水素反応沉いて， $\mathrm{Fe}_{2} \mathrm{O}_{3}$, limonite $\left(\mathrm{Fe}_{2} \mathrm{O}_{3} \cdot 3 \mathrm{H}_{2} \mathrm{O}\right)$, magnetite $\left(\mathrm{Fe}_{3} \mathrm{O}_{4}\right), \mathrm{Py}-$ rite $\left(\mathrm{FeS}_{2}\right)$ 它触媒とした時の反応速度定数を計算し

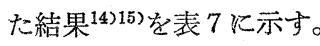

表 7 鉄触媒の速度定数 $\left(425^{\circ} \mathrm{C} \text { active site 当りの值 }\right)^{15)}$

\begin{tabular}{lrccc}
\hline \multicolumn{1}{c}{ 触 } & $10^{4} \mathrm{k}_{1}, \mathrm{sec}^{-1}$ & $10^{4} \mathrm{k}_{2}, \mathrm{sec}^{-1}$ & $10^{5} \mathrm{k}_{3}, \mathrm{sec}^{-1}$ & $10^{5} \mathrm{k}_{4}, \mathrm{sec}^{-1}$ \\
\hline $\mathrm{Fe}_{2} \mathrm{O}_{3}$ & 5.13 & 4.73 & 1.77 & 1.56 \\
$\operatorname{limonite}\left(2 \mathrm{Fe}_{2} \mathrm{O}_{3} \cdot 3 \mathrm{H}_{2} \mathrm{O}\right)$ & 5.78 & 5.26 & 0.78 & 0.76 \\
magnetite $\left(\mathrm{Fe}_{3} \mathrm{O}_{4}\right)$ & 3.66 & 2.06 & 3.36 & 2.61 \\
pyrite $\left(\mathrm{FeS}_{2}\right)$ & 6.53 & 3.13 & 8.27 & 4.81 \\
\hline
\end{tabular}

Tetralin $\underset{\mathrm{k}_{3}}{\stackrel{\mathrm{k}_{1}}{\rightleftarrows}}$ Dihydronaphthalene

$$
\underset{\mathrm{k}_{4}}{\stackrel{\mathrm{k}_{2}}{\rightleftarrows}} \text { Naphthalene }
$$

各定数は，ほぼ比例関係にあり，脱水素活性の大き な鉄化合物は，水素化活性る大きい傾向がある。

ここでGangwer は表面積について論じているが, Pyrite $2.2 \mathrm{~m} / \mathrm{g}$ であるのに比して limonite は 82.7 $\mathrm{m}^{2} / \mathrm{g}$ 亿も達する。したがって, 重量当りの触媒活性 は limonite がもっとも高いが, 表7 の結果は活性サ イト当りの值である。液化条件下では酸化鉄は鉄に (イオウが存在すれば硫化鉄に), Pyrite は Pyrrhotite $(\mathrm{FeS})$ に還元される（後述）ので, 表面積は当然変 化すると予想される。

鉄系触媒の場合, working state 飞扔いて, 化学構 造和よび表面積が著しく変化することに注意しなけれ ばならない。

Mathur ら ${ }^{16)}$ は各種鉱石の触媒効果を比較検討して いるが, Pyrite と limoniteを混合すると触媒作用が 向上するとの結果を得ている。

Garg $5^{17}$ は Hematite $\left(\mathrm{Fe}_{2} \mathrm{O}_{3}\right)$ の添加量, 粒径拉 よび水素王が脱硫，水素化反応にあた劣る影響を検討 しているが，添加量を増加してる反応率は一定值を超 劣ないという結果を認めている。

一般に鉄系触媒はモリブデン系触媒 に比して活性が低いが，固体触媒上の 反応では反応速度は表面積に比例する から，表面積の大きな試料を調製する か，またはできるだけ微細な粒子を分 散させるのがひとつの有力な対策であ る。

褐炭は，その構造内に多数のカルボ 
キシル基を含んでいる。Jackson ら ${ }^{18) 19)}$ はイオン交换 により $\mathrm{Fe}$ 抢よび $\mathrm{Sn}$ イオンを褐炭中に分散させて, 液化反応の触媒とする方法を検討した。反応温度にお いては，カルボキシル基は脱炭酸して，金属は微細な 状態で分散する。

表 8 に示すように, 少量の添加によってェーテル可 溶分 (X4可溶, 油, ガス) 叔よび $\mathrm{CH}_{2} \mathrm{Cl}_{2}$ 可溶分 (ア スファルテン, 油, ガス) に著しい増加が認められ る。

Jackson ら 20$)$ は鉄に少量の錫を添加した場合には相
乗効果を認めて打り, 図 1 に示すよらに, $400{ }^{\circ} \mathrm{C}$ 以上 に拈いてとくに著しい効果がある。 $\mathrm{Sn}$ の水素化促進 效果はあまり大きくないなど，作用機構は不明である が，少量の添加物により鉄触媒の効果を増加できるこ とは実用上きわめて重要である。

森田ら ${ }^{21) 22)}$ は11種の鉄鉣石にイオウを涯加（1:1） して, 液化反応に和ける触媒効果を比較しているが, 赤泥と同程度あるいはそれ以上の活性をもつものがあ ると述べている。本た， $\mathrm{Fe}(\mathrm{OH})_{3}-\mathrm{S}$ 系に対する $\mathrm{Ni}$, $\mathrm{Cu}, \mathrm{Zn}$ を添加すると活性が向上すると報告している。

表 8 イオン交換法により Fe およびSn イオンを担持したモーウェル褐炭の液化反応

\begin{tabular}{|c|c|c|c|c|c|c|}
\hline \multirow{2}{*}{ Coal Treatment } & \multirow{2}{*}{$\begin{array}{l}\text { Conc. of active } \\
\text { element } \\
\text { (mol/kg dry coal) }\end{array}$} & \multicolumn{4}{|c|}{ Mass $\%$ daf conversion to } & \multirow[b]{2}{*}{ Total } \\
\hline & & $\begin{array}{l}\mathrm{CH}_{2} \mathrm{Cl}_{2} \\
\text { sol. }\end{array}$ & $\begin{array}{l}\mathrm{X} 4 \\
\text { sol. }\end{array}$ & $\mathrm{H}_{2} \mathrm{O}$ & $\begin{array}{l}\text { Non-H } \\
\text { gas }\end{array}$ & \\
\hline Nil & $0.03(\mathrm{Fe})$ & 30 & 18 & 10 & 15 & 55 \\
\hline $0.05 \mathrm{M} \mathrm{FeSO} 4$ & $0.22(\mathrm{Fe})$ & 40 & 22 & 13 & 14 & 67 \\
\hline $0.001 \mathrm{M} \mathrm{SnCl}{ }_{2}$ & $0.03(\mathrm{Sn})$ & 38 & 24 & 14 & 13 & 65 \\
\hline $\begin{array}{c}0.05 \mathrm{M} \mathrm{FeSO}_{4} \text { and } \\
0.001 \mathrm{M} \mathrm{SnCl} \mathrm{Sn}_{2}\end{array}$ & $\begin{array}{l}0.32(\mathrm{Fe}) \\
0.02(\mathrm{Sn})\end{array}$ & 63 & 29 & 16 & 14 & 93 \\
\hline as for Run 4 & $\begin{array}{l}0.29(\mathrm{Fe}) \\
0.02(\mathrm{Sn})\end{array}$ & 63 & 28 & 15 & 15 & 93 \\
\hline $0.0065 \mathrm{M} \mathrm{SnCl} \mathrm{Sn}_{2}$ & $0.17(\mathrm{Sn})$ & 61 & 29 & 16 & 12 & 89 \\
\hline
\end{tabular}

反応条件：褐炭 $50 \mathrm{~g}$, テトラリン $50 \mathrm{~g}$, 水素初圧 $100 \mathrm{bar}$, 昇温時間 90 分, 反応温度 $375 \pm 5{ }^{\circ} \mathrm{C}$, 時間 60 分, $1 \ell$ ロキングオートクレーブ使用
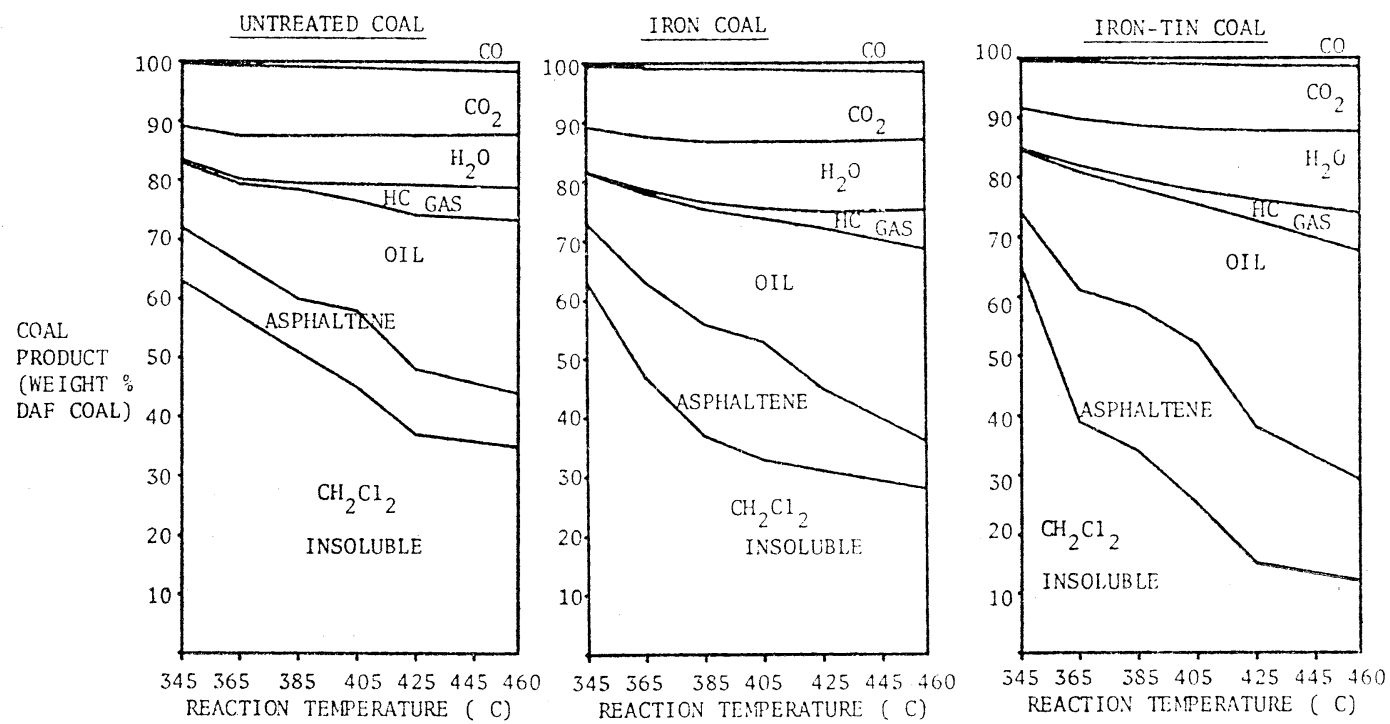

（触媒濃度は表 9 の実験番号 No.1，No.2，No.4 に相当）

図 1 褐炭液化における Fe および Fe-Sn 触媒の効果 ${ }^{20)}$ 
石炭中の鉱物質は相当量のPyrite を含んで拈り， 米国東部の歴青炭はとくに含有量が高い。Gulf 社に より開発された SRC-II プロセスは，未反応残渣を循 環して含有硫化鉄の触媒効果を利用する方式である。 石炭内部に分散している硫化鉄にどの程度の活性があ るかは興味のある所であるが，皦密な評価は難かし い。乙かし，残渣に含まれる鉱物質传触媒作用がある ことは事実であり，添加により液化生成物中の軽質分 が增加する様相 ${ }^{34)}$ は図 2 亿例示する通りである。

Derbyshire ら゙タ $\mathrm{HF}$ と $\mathrm{HCl}$ で石炭を処理し, Pyrite を除去した試料について実験した結果，短時 間の液化に执いては除去の影響がなく，長時間でしか も水素供与性の低い、溶媒中では, 反応率打よび水素消 費量に明白な相違が認められると述べている。

灰分中の鉄化合物の含有量は石炭により異なるが， 定性的には灰分の含有量と触媒効果の間に比例関係が 認められるといら報告を図 3 亿示す。各種米国炭の場 合, 灰分の $w t \%$ 飞対して, 水素の存在下と非存在下

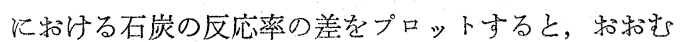
叔比例関係が認められる。

図 2 石炭液化残渣添加量が液化生成物 分布に与える影響 34

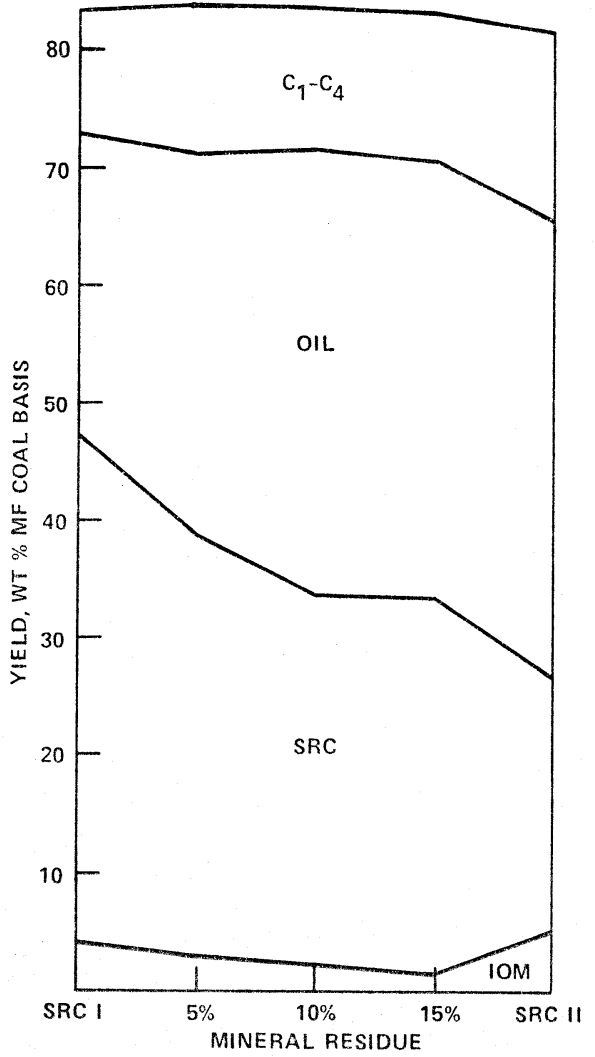

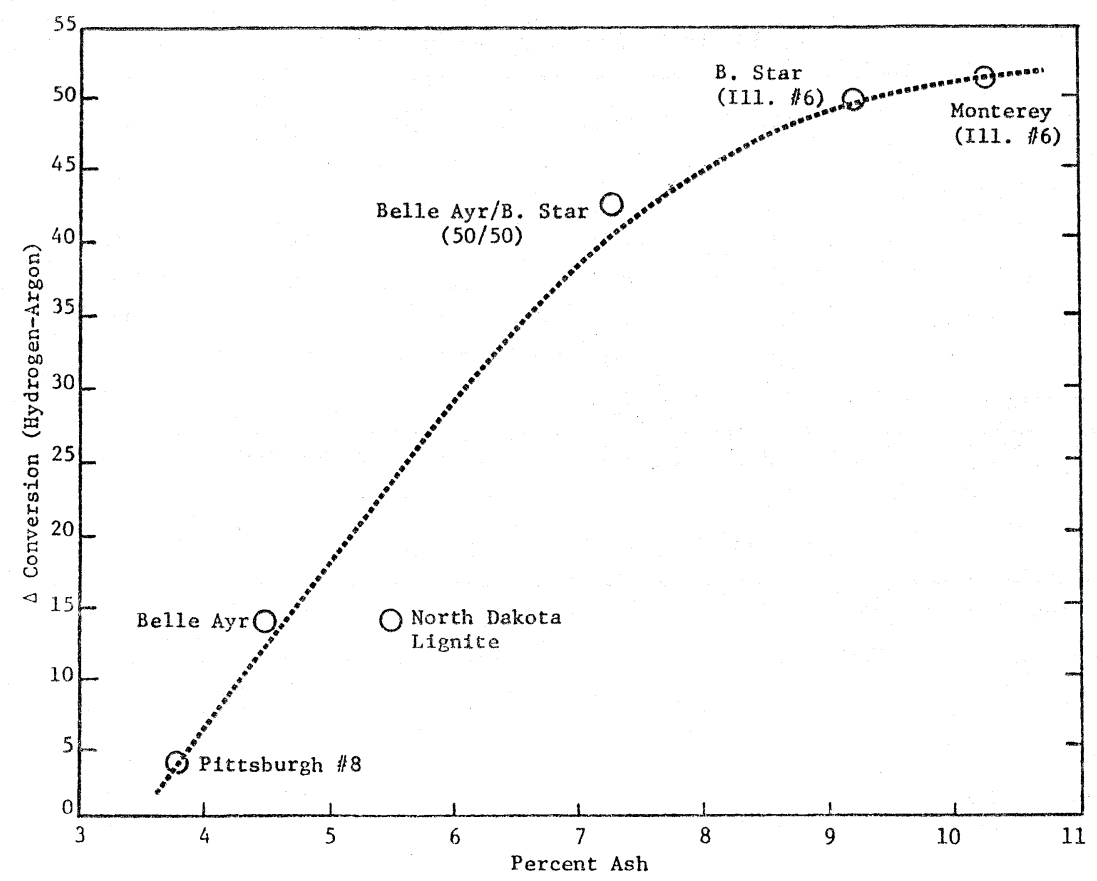

(反応条件： $750^{\circ} \mathrm{F}, 60$ 分, $70 \mathrm{~kg} / \mathrm{cm}^{2}$, ピレン/石炭 $=3 / 1$ )

図 3 石炭の灰分含有量と水素化反応の効果 ${ }^{6}$ 


\section{3. 硫化鉄系触媒の作用機構について}

天然の Pyrite は純粋の $\mathrm{FeS}_{2}$ ではない。分析例は 表 9 に示すように, $\mathrm{FeS}_{2}$ として $84 \%$ であり, 表面積 が著しく小さい $\left(1 \mathrm{~m}^{2} / \mathrm{g}\right.$ 程度)という特徴がある。

表10は各種 Pyrite 特よび使用後の Pyrite を石炭 液化触媒として使用した結果の比較である。無添加の 場合に比して, オイルが著しく増加し, IOM, アスフ アルテンおよびプレアスファルテンが減少して拉り, 触媒効果が大きいが，Pyrite の種類による差はあま り大きくない。

鉄系触媒の添加量についつは，実用上はあまり高く

表 9 Pyrite の分析值 ${ }^{10)}$

\begin{tabular}{lr}
\hline & wt $\%$ \\
\hline carbon & 4.48 \\
hydrogen & 0.34 \\
nitrogen & 0.61 \\
sulfur & 41.34 \\
oxygen & 5.97 \\
iron & 42.30 \\
other impurities (by difference) & 4.96 \\
total & 100.0 \\
surface area $=1.0 \mathrm{~m}^{2} / \mathrm{g}$ & \\
\hline
\end{tabular}

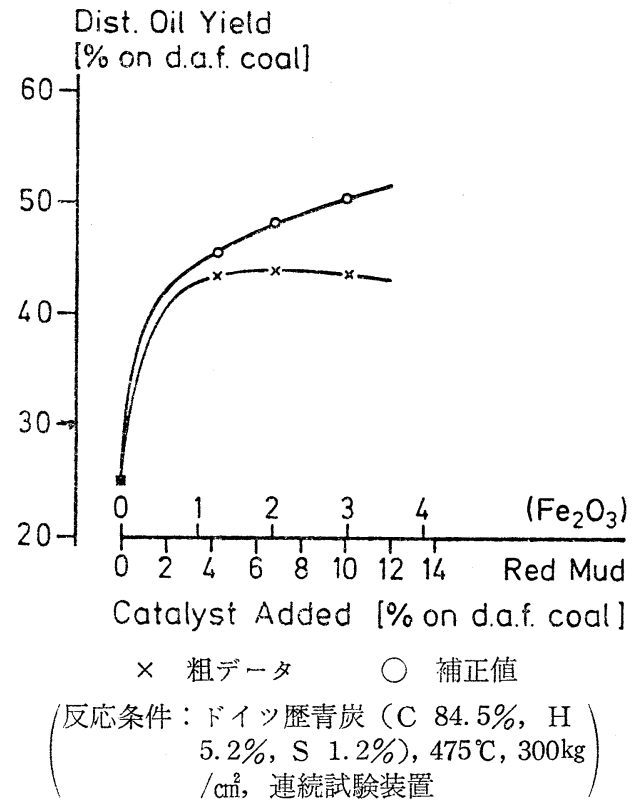

図 4 鉄触媒添加量の効果 ${ }^{27}$

表 10 各種 Pyrite の 活性 比 較24)

\begin{tabular}{ccccccc}
\hline Pyrite & None & Robena & Siniola & $\begin{array}{c}\text { South } \\
\text { Dakota }\end{array}$ & MCB & $\begin{array}{c}\text { Spent } \\
\text { Pyrite }\end{array}$ \\
\hline $\begin{array}{c}\text { MAF Coal Percent } \\
\text { Oil }\end{array}$ & 16 & 39 & 47 & 48 & 46 & 47 \\
Asphaltene & 48 & 44 & 29 & 29 & 28 & 25 \\
Preasphaltene & 13 & 7 & 9 & 10 & 10 & 10 \\
IOM & 23 & 10 & 15 & 13 & 16 & 18 \\
Conversion & 77 & 90 & 85 & 87 & 84 & 82 \\
\hline
\end{tabular}

反応条件: 石炭 Elkhorn No. $3,450^{\circ} \mathrm{C}$, 水素王 $90 \mathrm{~kg} / \mathrm{cm}^{2}, 60$ 分, 石炭 $/$ 溶媒 $=1 / 2$

表 11 Pyrite 濃 度 の 効 果 ${ }^{25)}$

\begin{tabular}{lcccrrr}
\hline Pyrite Concentration (g) & 0 & 0.25 & 0.5 & 1.0 & 2.0 \\
Concentration wt \% of Coal & 0 & 8.0 & 17.0 & 33.0 & 66.0 \\
\hline Oil & 16 & 37 & 46 & 46 & 62 \\
Asphaltene & 48 & 38 & 33 & 39 & 26 \\
Preasphaltene & 13 & 9 & 7 & 7 & 6 \\
IOM & 23 & 16 & 14 & 8 & 9 \\
Conversion & 77 & 84 & 86 & 92 & 94 \\
\hline
\end{tabular}

区応条件：表10に同じ，Robena pyrite 
ない方がよいことが Strobel27) とより主張されてい る。理論的には石炭の水素化分解は添加量に比例する と予測されるが，無機分が多いと減圧蒸留による留出 油の実際の取得量が低下し，また軽質油の分解による 炭化水素ガスの生成量が増加するため汇, $\mathrm{Fe}_{2} \mathrm{O}_{3}$ とし て $2 \mathrm{wt} \%$ 程度が最適で㐫るという（図 4 ）。

$450^{\circ} \mathrm{C}$ に执いて, Pyrite の添加量の効果を検討した 結果（表11）によると，濃度に比例して石炭の溶解反 応，アスファルテン拈よびプレアスファルテンの分解 が促進され，オイルの収率（分解ガスを含む）が増加 する傾向が認められる。Pyrite の添加量が大きいと， 反応条件下では，

$$
\mathrm{FeS}_{2} \stackrel{\mathrm{H}_{2}}{\longrightarrow} \mathrm{FeS}+\mathrm{H}_{2} \mathrm{~S}
$$

のような反応が叔こり, 相当量の $\mathrm{H}_{2} \mathrm{~S}$ を生成し, $\mathrm{H}_{2} \mathrm{~S}$ が水素供与体として働き，石炭の液化反応を促進する 効果も劣ると考兄られる。
Pyrite は微粉䂶する注ど表面積が大きくなり，反 応速度が大になると期待される。とくに表面積の小さ 、物質について潘粉碎の效果が大きい筈であるが，表 12に示した結果によると，180 $\mu$ 以下に粉研してもオ イルの取率に大きな効果が認められない。これは後述 するように，化学構造の変化にともない表面積に変化 が持こることも一因と考光られる。

鉄系触媒の場合, 添加量を增加しても， をた微粉碎 しても，石炭液化に対してあまり效果江差がなく，一 定の限界值に収束する傾向が認められることがある。 液化反応が複雑な逐次反応であり, 分解と同時任重合 をともない易いことなども考虑淔するが，鉄系触媒 で高度の水素化分解を行うには, 高温, 高水素圧を適 用する必要があるため，水素圧が充分㵝高くなかった のではないかという疑問がもたれる。

$\mathrm{FeS}_{2}$ と FeS 比較したのが表13である。るっとも好結果を与えたる

表 12 Pyrite 粒 徍 $の$ 効 果26)

\begin{tabular}{lcccccc}
\hline \multicolumn{1}{c}{ Wt $\%$} & None & $+350 \mu$ & $350-180 \mu$ & $180-100 \mu$ & $100-75 \mu$ & $-50 \mu$ \\
\hline Gas & 11 & 9 & 9 & 9 & 10 & 10 \\
Oil & 21 & 36 & 37 & 38 & 38 & 39 \\
Asphaltene & 36 & 29 & 30 & 28 & 28 & 38 \\
Preasphaltene & 12 & 12 & 11 & 13 & 12 & 7 \\
IOM & 20 & 14 & 13 & 12 & 12 & 6 \\
Conversion & 80 & 86 & 87 & 88 & 88 & 94 \\
\hline
\end{tabular}

反応条件：石炭 Elkhorn No. 3

表 13 各穤 $\mathrm{FeS}_{2}$ む̋よび $\mathrm{FeS}$ 触蝶効果の比較28)

\begin{tabular}{lrrrrrrr}
\hline \multicolumn{1}{c}{ Catalyst } & - & $\mathrm{FeS}_{2}{ }^{\mathrm{a}}$ & $\mathrm{FeS}_{2}{ }^{\mathrm{b}}$ & $\mathrm{FeS}^{\mathrm{c}}$ & $\mathrm{FeS}^{\mathrm{d}}$ & $\mathrm{FeS}^{\mathrm{e}}$ & $\mathrm{FeS}^{\mathrm{f}}$ \\
\hline $\begin{array}{l}\text { Conversion (\% daf coal) } \\
\text { Benzene Solubles }\end{array}$ & 61 & 78 & 78 & 71 & 76 & 78 & 78 \\
THF Solubles & 85 & 96 & 96 & 92 & 92 & 95 & 93 \\
Product Yield (\% daf coal) & & & & & & & \\
$\mathrm{C}_{1}-\mathrm{C}_{4}$ & 3.1 & 2.7 & 2.9 & 2.9 & 2.9 & 3.0 & 3.3 \\
$\mathrm{CO}_{\mathrm{CO}} \mathrm{CO}_{2}$ & 1.5 & 0.8 & 1.3 & 1.4 & 1.3 & 0.8 & 1.2 \\
$\mathrm{H}_{2} \mathrm{~S}$ & 1.5 & 5.1 & 7.0 & 2.5 & 3.9 & 3.5 & 4.3 \\
Oil & 13.9 & 24.6 & 35.7 & 13.1 & 24.1 & 30.5 & 22.2 \\
Asphaltenes & 43.9 & 49.9 & 36.7 & 54.3 & 48.0 & 45.0 & 52.0 \\
Preasphaltenes & 24.6 & 17.2 & 17.6 & 21.8 & 16.5 & 17.4 & 15.5 \\
IOM & 14.8 & 4.4 & 4.1 & 7.7 & 7.7 & 4.6 & 6.7 \\
Hydrogen Consumed & -3.3 & -4.7 & -5.3 & -3.7 & -4.4 & -4.8 & -5.2 \\
\hline
\end{tabular}

${ }^{2} 100 \times 200$ mesh. ${ }^{b}-325$ mesh. "Cerac/pure. "Gallard-Schlesinger. "Freshly precipitated.

${ }^{\mathrm{f}} \mathrm{Hydrothermally} \mathrm{synthesized.}$ 
表 14 各種硫化鉄の表面積と触媒効果の比較 ${ }^{29}$

\begin{tabular}{lc}
\hline \multicolumn{1}{c}{ Compound } & $\begin{array}{c}\text { Surface Area } \\
\left(\mathrm{m}^{2} / \mathrm{g}\right)\end{array}$ \\
\hline Robena Pyrite & 3.5 \\
Cleaned Robena Pyrite & 2.2 \\
Pyrite & \\
I Chemically ppt. & 10.0 \\
II Annealed $180^{\circ} \mathrm{C}$ & 4.9 \\
III Annealed $230^{\circ} \mathrm{C}$ & 2.1 \\
Pyrrhotite & \\
I Liquefaction Residue & 10.4 \\
$\quad$ (4 ${ }^{\circ} \mathrm{C}$ Mackinawite) & 5.7 \\
II Residue (Robena) & \\
Mackinawite & 80.0 \\
I Chemically ppt. $4^{\circ} \mathrm{C}$ & 40.0 \\
II Chemically ppt. R. T.
\end{tabular}

\begin{tabular}{lccc}
\hline \multicolumn{1}{c}{ Catalyst } & $\begin{array}{c}\text { Toluene Sols } \\
(\% \text { daf) }\end{array}$ & THF Sols & $\begin{array}{c}\text { Residue SA } \\
\left(\mathrm{m}^{2} / \mathrm{g}\right)\end{array}$ \\
\hline None & $43 \pm 2$ & $65 \pm 4$ & \\
Robena Pyrite & 49 & 69 & \\
Cleaned Robena & 50 & 71 & $\begin{array}{c}5.7 \\
\text { (pyrrhotite) }\end{array}$ \\
Pyrite I & 49 & 70 & \\
Pyrite II & 50 & 72 & \\
Pyrite III & 48 & 74 & \\
Pyrrhotite I & 47 & 70 & \\
Pyrrhotite II & 47 & 69 & (pyrrhotite) \\
Mackinawite I & 48 & 73 & \\
Mackinawite II & 47 & 67 & \\
\hline
\end{tabular}

表 15 硫化鉄の表面積に対する温度および時間の効果 ${ }^{30)}$

\begin{tabular}{|c|c|c|c|c|c|}
\hline 硫 化 鉄 & $\begin{array}{l}\text { 初 期 } \\
\text { 表面 績 } \\
\left(\mathrm{m}^{2} / \mathrm{g}\right)\end{array}$ & $\frac{\text { 処 }}{\text { 瑥度 }\left({ }^{\circ} \mathrm{C}\right)}$ & $\underbrace{\text { 条 件 }}_{\text {時間(min) }}$ & $\begin{array}{l}\mathrm{X} \text { 線分析 } \\
\text { ピーク高さ }\end{array}$ & $\begin{array}{c}\text { 処理後の } \\
\text { 表 面 積 } \\
\left(\mathrm{m}^{2} / \mathrm{g}\right)\end{array}$ \\
\hline $\mathrm{Fe}_{9} \mathrm{~S}_{8}$ & 80 & 250 & 30 & Very small $\mathrm{Fe}_{1-\mathrm{x}} \mathrm{S}$ & 52 \\
\hline $\mathrm{Fe}_{9} \mathrm{~S}_{8}$ & 80 & 350 & 30 & Large $\mathrm{Fe}_{1-x} \mathrm{~S}$ & 12 \\
\hline $\mathrm{Fe}_{9} \mathrm{~S}_{8}$ & 80 & 425 & 30 & Large $\mathrm{Fe}_{1-x} \mathrm{~S}$ & 10 \\
\hline $\mathrm{Fe}_{9} \mathrm{~S}_{8}$ & 80 & 425 & $<0.5$ & Large $\mathrm{Fe}_{1-\mathrm{x}} \mathrm{S}$ & 11 \\
\hline $\mathrm{FeS}_{2}$ & 2.2 & 425 & $<0.5$ & Large $\mathrm{Fe}_{1-x} \mathrm{~S}$ & 5 \\
\hline $\mathrm{FeS}_{2}$ & 2.2 & 425 & 30 & Large $\mathrm{Fe}_{1-\mathrm{x}} \mathrm{S}$ & 6 \\
\hline
\end{tabular}

のは，325mesh 以下に微粉砕した $\mathrm{FeS}_{2}$ であり，つ いで調製直後の沈殿 FeS であった。Granoff ら 29 は さらに, Pyrite, Pyrrhotite (FeS), Mackinawite $\left(\mathrm{Fe}_{9} \mathrm{~S}_{8}\right)$ について詳細な検討を行っているが， $\mathrm{FeS}_{2}$ は

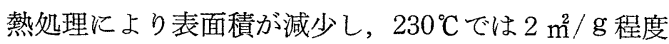
になる。Pyrrhotite は液化反応後で $6 \sim 10 \mathrm{~m}^{2} / \mathrm{g}$ であ り，Mackinawite は調製時の表面積が大きいが(40 $\sim 80 \mathrm{~m}^{2} / \mathrm{g}$ )，これを用いて石炭液化反応を行った場 合, トルェン可溶分执よびTHF 可溶分にあまり大き な差はなく，むしろ Pyrite の方がわずかに好結果を 与えるようである(表14)。

この理由として Stephens ら ${ }^{30}$ は，表面積の大きい $\mathrm{Fe}_{9} \mathrm{~S}_{8}$ でも, $425^{\circ} \mathrm{C}$ では $10 \mathrm{~m}^{2} / \mathrm{g}$ 程度に表面積が低下す ること, 表面積の小さい $\mathrm{FeS}_{2}(2.2 \mathrm{~m} / \mathrm{g})$ は逆に425 ${ }^{\circ} \mathrm{C}$ で処理することにより表面積が $5 \sim 6 \mathrm{~m}^{2} / \mathrm{g}$ に増加 することを報告している（表15）。

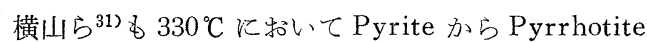

への形態変化が扣こり, 表面積の増加が観察されるこ とを報告している。

したがって，硫化鉄はどのような形態で添加して も，若干の $\mathrm{H}_{2} \mathrm{~S}$ が共存すれば，表面的には同様な性 状の化合物に変化している可能性がある。このような 事情は，表面積の大きな酸化鉄，水酸化鉄あるいは鉄 粉とイオウの組み合わせ触媒においても, 反応条件に よっては，有効表面積の低下が括こることを示唆して 拈り，乙たがって，液化条件に拈いて大きな表面積の 大きな触媒を調製することが，重要なポイントとなる であろら。

高活性触媒の開発のためには，基礎研究の成果が重 要な示唆を与えるものと考えられる。

Stephens ら ${ }^{30)} は$ また, $\mathrm{FeS}_{2}$ または $\mathrm{Fe}_{(1-\mathrm{x})} \mathrm{S}+$ $\mathrm{H}_{2} \mathrm{~S}$ を用いると, $\mathrm{Fe}_{(1-\mathrm{x})} \mathrm{S}$ あるいは $\mathrm{H}_{2} \mathrm{~S}$ を単独で用 いるよりも好結果が得られることを報告している（表 16)。 
表 16 石炭液化における $\mathrm{FeS}_{2}, \mathrm{Fe}_{(1-\mathrm{X})} \mathrm{S}, \mathrm{H}_{2} \mathrm{~S}$ の効果 ${ }^{30)}$

\begin{tabular}{|c|c|c|c|}
\hline 添 加 物 & 量 & アスファルテン & オイル \\
\hline None & - & $30.2 \pm 1.8$ & $27.0 \pm 1.6$ \\
\hline $\mathrm{H}_{2} \mathrm{~S}$ & $3 \mathrm{~mol} \%$ & 29.7 & 30.6 \\
\hline $\mathrm{Fe}_{(1-x)} \mathrm{S}$ & $7.5 \mathrm{wt} \%$ & 36.8 & 33.5 \\
\hline $\mathrm{FeS}_{2}$ & 7.5 wt $\%$ & 36.8 & 42.0 \\
\hline$\left\{\begin{array}{l}\mathrm{Fe}_{(1-x)} \mathrm{S} \\
\text { 屯よび } \\
\mathrm{H}_{2} \mathrm{~S}\end{array}\right.$ & $\left.\begin{array}{l}7.5 \mathrm{wt} \% \\
3.0 \mathrm{~mol} \%\end{array}\right\}$ & 34.6 & 42.7 \\
\hline
\end{tabular}

反応条件： $425^{\circ} \mathrm{C}, 30$ 分, $70 \mathrm{~kg} / \mathrm{cm}^{2}$

奥谷ら ${ }^{35)}$ も各種触媒を用いた液化反応に括いて, $\mathrm{H}_{2}+\mathrm{H}_{2} \mathrm{~S}$ は $\mathrm{H}_{2}$ よりもはるかに効果があることを認め ている。 $\mathrm{H}_{2} \mathrm{~S}$ が触媒上で分解して水素を発生し，これ が反応に関与するとの説は興味深いが， $\mathrm{H}_{2} \mathrm{~S}$ の效果が すべての金属酸化物について顕著に認められるので， $\mathrm{H}_{2} \mathrm{~S}$ の水素供与性によると考光る方が無理がないので はあるまいか。

石炭液化によるオイルの生成反応に対して，FeSの みならず $\mathrm{H}_{2} \mathrm{~S}$ も有効であり，かつ相乗効果が認めら れることは重要な知見である。
水素化反応は水素王に比例して進行するが，圧力を 1,000 から $3,000 \mathrm{psi}$ 飞変化させた場合, 表 17 に示すよ らに圧力と水素消費量は值線関係にある。生成油につ いては, 水素化分解が進行するために, 圧力に比例し て留出油が増加し, 残渣が減少する。また, 脱硫効果 も明瞭で，高压になるほど生成油のイオウ含有量は低 下する。

石炭の液化反応は非常に多くの反応から成り立って いる。大きく分類しても, 水素化反応, 水素化分解反 応, 水素化脱硫, 一脱酸素, 一脱空素, などであり, 反 応機構の観点からモデル化合物を用いた詳細な検討が 必要である。

Derbyshire ら ${ }^{8)}$ によれば, フェナントレンの水素 化（表18）に和ける Pyrite の性能は，Co-Mo 系触 媒に比してはるかに低いが，ピレンの水素化（表19） に対してはかなり高いと報告されている。ジヒドロピ レンは直ちに分解して, 低分子化する中間体ではない が, 水素供与体ないし水素化剂として液化反応に重要 な影響を与える化合物である。

鉄系触媒による脱硫反応については, Guin ら ${ }^{32) 333}$ による報告があり，かなりの速度で進行することが確 かめられている。しかし，脱酸素および脱窒素反応に

表 17 石炭液化における水素分圧の効果 ${ }^{10)}$

\begin{tabular}{|c|c|c|c|c|c|}
\hline initial pressure, psig & 3,000 & 2,500 & 2,000 & 1,500 & 1,000 \\
\hline $1-\mathrm{H}_{\mathrm{f}} / \mathrm{H}_{0}$ & 0.44 & 0.49 & 0.52 & 0.47 & 0.55 \\
\hline $\mathrm{H}_{2}$ used, $\mathrm{g}$ & 0.52 & 0.47 & 0.40 & 0.27 & 0.20 \\
\hline \multicolumn{6}{|l|}{$\begin{array}{l}\text { distillation product } \\
\text { distribution, } \%\end{array}$} \\
\hline top (oil) & 71.0 & 70.0 & 70.0 & 67.0 & 67.0 \\
\hline bottom (SRC) & 29.0 & 30.0 & 30.0 & 33.0 & 33.0 \\
\hline \multicolumn{6}{|l|}{ sulfur distribution, $\%$} \\
\hline SRC & 0.37 & 0.42 & 0.57 & 0.50 & 0.56 \\
\hline total & 0.15 & 0.20 & 0.25 & 0.24 & 0.25 \\
\hline
\end{tabular}

反応条件：石炭 Kentucky No. 9, $410^{\circ} \mathrm{C}$, 添加物 Hematite $5 \mathrm{~g}$ (反応混合物の $4 \mathrm{wt} \%$ ), 120分, $\mathrm{H}_{\mathrm{f}} / \mathrm{H}_{\mathrm{o}}$ は水素終圧 /初圧比, 生成物 top $270^{\circ} \mathrm{C}$ 留出物 $/ 1 \mathrm{mmHg}$

表 18 フェナントレンの水素化における 各種触媒効果 ${ }^{8)}$

$\left(700^{\circ} \mathrm{F}\right.$, 水素生 $\left.100 \mathrm{~kg} / \mathrm{cm}^{2}\right)$

\begin{tabular}{lc}
\hline \multicolumn{1}{c}{ 触媒 } & $\begin{array}{c}\text { フェナントンンの } \\
\text { 水素化度 }\end{array}$ \\
\hline $\mathrm{Co}-\mathrm{Mo} / \mathrm{Al}_{2} \mathrm{O}_{3}$ & 32 \\
$\mathrm{FeS}_{2}$ & 3 \\
石炭液化残渣 & 1.5 \\
Vycor $\left(\mathrm{SiO}_{2}\right)$ & 1.3 \\
\hline
\end{tabular}

表 19 ピレンの水素化における触媒効果 ${ }^{8)}$ $\left(750^{\circ} \mathrm{F}\right.$ ，水素王 $140 \mathrm{~kg} / \mathrm{cm}^{2} ， 1$ 時間)

\begin{tabular}{lc}
\hline \multicolumn{1}{c}{ 触 } & $\begin{array}{c}\text { ジヒドロピレンヘ } \\
\text { の転化率 }\end{array}$ \\
\hline None & 1.8 \\
$10 \%$ Pyrite & 7.2 \\
$10 \% \mathrm{MoO}_{3}$ & 11.6 \\
$10 \% \mathrm{Co}-\mathrm{Mo} / \mathrm{Al}_{2} \mathrm{O}_{3}$ & 26.9 \\
\hline
\end{tabular}


ついては,きわめて荤いと考光られている。

したがって，石炭液化によりクリーンな燃料油を生 成するためには，はじめの反応で生成した液化油をモ リブデン系触媒を用いて水素化精製する, いわわるア ップグレーディングの過程が必須で方る。

\section{4. おわりに}

石炭り水素化分解によりクリーンな留出油学生成す るためには，触媒を用いることが必須であるが，第一. 段階では活性の高い鉄系触媒を使用すること，第二段 階では寿命の長いモりブデン系触媒を使用することが 適当な対策であるとい方よう。

鉄系触媒については旧い歴史があるが，その作用機 構はほとんど不明であり，化合物の形態にはあまり閖 係がないという見解，あるいはきわめて活性の高い化 合物を調製できるといら過大な期待があったように思 われる。しかし, 最近の多くの研究成果により, 鉄系 触某の作用機構および触媒開発に执いて留意す心゙き要 点がほぼ明らかにされてきたことは喜ばしいことであ る。

わが国の石炭液化プロジェクトも大型パイロットプ ラントを計画・建設する段階に発展している。鉄系触 媒の特長を生かした優れた触媒系が開発され，わが国 独自の新しい経済的な石炭液化プロセスが誕生するこ とを心から希望して筆を置く。

\section{文献}

1）神谷佳男，然協誌，60，815（1981）

2) 神谷住男, 化学の領域, 34, 90 (1980)

3）坂部 孜，燃協誌， 55,809 (1976)

4) 神谷佳男, 燃協誌, 58, 2 (1979)

5）神谷佳男，然協誌，56，319（1977）

6) Derbyshire, F. J. and Whitehurst, D. D., Fuel, 60, 655 (1981)

7) Kamiya, Y., Yao, T. and Nagae, S., Intl. Conference Coal Science, C-13, P. 398 Düsseldorf, Sept. 1981

8) Derbyshire, F. J., Varghese, P. and Whitehurst, D. D., Intl. Conference Coal Science, C-6, 356 Düsseldorf, Sept. 1981

9) Shah, Y. T. and Cronauer, D. C., Catal. Rev. Sci. Eng., 20, (2) 209 (1979)

10) Garg, D. and Givens, E. N., Ind. Eng. Chem. Proc. Des. Dev., 21, 113 (1982)

11) Kamiya, Y., Nagae, S., Yao, T., Hirai, H. and Fukushima, A., Fuel, 印刷中

12) Alexander, B. F. and Anderson, R. P., Amer. Chem. Soc. Div. Fuel, 27, (2) 18 (1982)

13) Guin, J. A., Taner, A. R., Lee, J. M., VanBackle, H. F. and Curtis, C. W., Ind. Eng. Chem. Proc. Des. Dev., 18, 630 (1979)

14) Gangwer, T. E. and Prasad, H., Fuel, 58,
577 (1979)

15) Gangwer, T. E., J. Phys. Chem., 85, 575 (1981)

16) Mathur, V. K. and Venkataramanan, V., Amer. Chem. Soc. Div. Fuel, 27, (2) 1 (1982)

17) Garg, D., Tarrer, A. R., Guin, J. A., Curtis, C. W. and Clinton, J. H., Ind. Eng. Chem. Proc. Des. Dev., 19, 572 (1980)

18) Hatswell, M. R., Jackson, W. R. and Larkins, F. P., Fuel, 59, 442 (1980)

19) Marshall, M., Jackson, W. R., Larkins, F. P., Hatswell, M. R. and Rash, D., Fuel, 61, 121 (1982)

20) Cassidy, P. J., Larkins, F. P. and Jackson, W. R., Amer. Chem. Soc. Div. Fuel, 27, (2) 28 (1982)

21）森田程, 池添光則, 橋本孝雄, 佐藤志美雄, 今泉 武男，二瓶裕之，燃協誌，61，42（1982）

22）橋本孝雄, 豊嶋弘幸, 今泉武男, 池添光則, 佐藤 志美雄, 森田稪, 然協誌, 60, 21 (1981)

23) Kamiya, Y., Oikawa, S. and Nagae, S., Fuel, 投稿中

24) DOE Technical Progress Report Sept. 1Nov. 30, 1980

FE 4806-15, Air Products and Auburn Univ.

25) DOE Technical Progress Report June 1Aug. 31, 1980

FE 14806-12, Air Products and Auburn Uuiv.

26) Huang, W. J., Curtis, C. W., Guin, J. A., Clinton, J. H., Barwood, H. C. and Tarrer, A. R., AIChE Meeting, Houston, April, 1981

27) Strobel, B. and Friedlich, F., Intl. Conference Coal Science, C-38, P. 556, Düsseldorf, Sept. 1981

28) Granoff, B. and Baca, P. M., Sandia Lab. Energy Report, 79-0505, April, 1979

29) Stohl, F. V. and Granoff, B., Sandia Lab. Energy Report 80-2361 C

30) Stephens, H. P., Stohl, F. V. and Padrick, T. D., Intl. Conference Coal Science, C-8, p. 368, Düsseldorf, Sept. 1981

31）横山慎一, 成田英夫，小松紘平，吉田諒一，前河 涌典, 第18回石炭科学会議論文集, p.15, 昭和56 年10月

32) Guin, J.A., Tarrer, A. R., Lee, J. M., Lo, L. and Curtis, C. W., Ind. Eng. Chem. Proc. Des. Dev., 18, 371 (1979)

33) Guin, J. A., Lee, J. M., Fan, C. W., Curtis, C. W., Lloyd, J. L. and Tarrer, A. R., ibid., 19, 440 (1980)

34) Moroni, E. C., Proceedings 5 th EPRI Contractor's Conference Coal Liquefaction Sect. 7, May, 1980 Palo Alto. 
35）奥谷猛, 横山慎一, 前河涌典, 古市隆三郎, 石井 年11月 忠雄，第15回石炭科学会議論文集，p.78，昭和53

\title{
Effect of Iron Catalysts on Coal Liquefaction
}

\author{
Yoshio KAMIYA \\ $\left(\begin{array}{l}\text { Faculty of Engineering, } \\ \text { University of Tokyo }\end{array}\right)$
}

SYNOPSIS:-Recent works on the effect of iron catalyst on direct coal liquefaction reaction were reviewed from catalytic point of view. Various types of iron compounds such as sulfides, oxides and metallic iron are effective for coal dissolution step, because they enhance the hydrogen donating property of solvent by hydrogenating aromatic nucleus. As well, iron catalysts play an important role in coal liquefaction by hydrocracking and hydrodesulfurizing coal fragments. The most effective form of iron catalyst at the working state in coal liquefaction was discussed.

\section{Key Words}

Coal liquefaction, Iron catalyst 